\title{
Morpho-anatomy of the leaf and stem of Eugenia pyriformis
}

\section{Lorene Armstrong, ${ }^{1}$ Márcia do Rocio Duarte, ${ }^{* 2}$ Obdulio Gomes Miguel $^{3}$}

${ }^{1}$ Programa de Pós-graduação em Ciências Farmacêuticas, Universidade Federal do Paraná, Brazil,

${ }^{2}$ Laboratório de Farmacognosia, Departamento de Farmácia, Universidade Federal do Paraná, Brazil,

${ }^{3}$ Laboratório de Fitoquímica, Departamento de Farmácia, Universidade Federal do Paraná, Brazil.

\begin{abstract}
Eugenia pyriformis Cambess., known as uvaia, is a species of Myrtaceae native to Brazil. Its leaves are used in folk medicine to treat gout because they possess the property of inhibiting xanthine oxidase, an enzyme involved in the conversion of xanthine into uric acid. The objective of this work was to study the leaf and stem morphoanatomy of E. pyriformis, in order to contribute to what is known about the Brazilian flora, and this medicinal plant and potential vegetal drug. Samples of mature leaves and young stems were fixed and sectioned by freehand, or embedded in glycol methacrylate and sectioned with a microtome, and then stained. In addition, microchemical tests and scanning electron microscopy were performed. The leaf is simple, symmetric, ellipticlanceolate, with an acute apex and base, and an entire margin. The epidermis is uniseriate and coated with a moderately thick cuticle. The stomata are anomocytic and inserted at the same level as the adjacent cells. Unicellular non-glandular trichomes are abundant on the abaxial surface. The mesophyll is dorsiventral. In transverse section, the midrib is plano-convex and the petiole is circular, and both of these structures have a single bicollateral vascular bundle. In the stem, the vascular cylinder consists of external phloem, xylem and internal phloem, traversed by narrow rays. Phenolic compounds, druses and prismatic crystals of calcium oxalate are also present in the leaf and stem.
\end{abstract}

Revista Brasileira de Farmacognosia Brazilian Journal of Pharmacognosy 22(3): 475-481, May/Jun. 2012

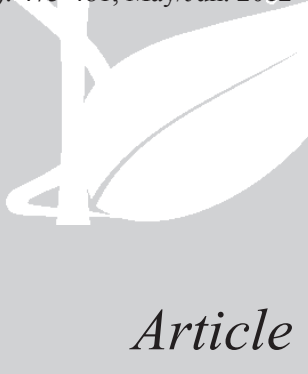

Article

Received 4 Sep 2011

Accepted 22 Dec 2011

Available online 31 Jan 2012

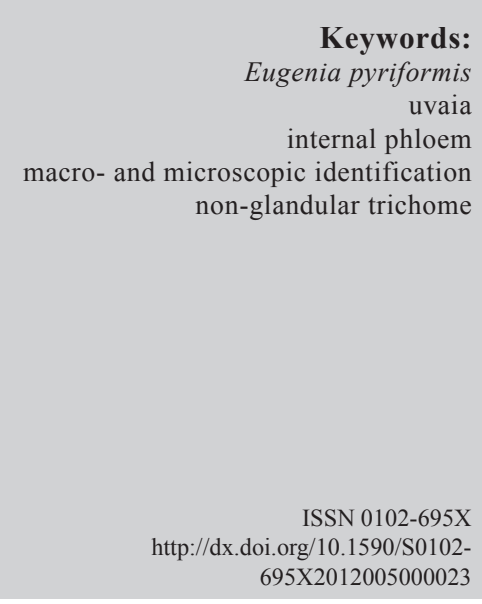

\section{Introduction}

The family Myrtaceae Juss. consists of 130 genera and 4000 species (Souza \& Lorenzi, 2005), and has its largest centers of diversity in the Americas and Oceania (Joly, 1998). In Brazil it is one the largest families with approximately 23 genera and 1000 species distributed throughout the country, and is especially diverse in the Atlantic Forest and restinga (Souza \& Lorenzi, 2005).

The genus Eugenia L. is an important taxon because it has nutritional, commercial and therapeutic value (Donadio, 2002; Silva et al., 2003). Studies on E. beaurepairiana (Kiaersk.) D. Legrand demonstrated that the leaf of this species has anti-inflammatory properties when topically administered (Magina et al., 2009). In a revision by Auricchio \& Bacchi (2003) on E. uniflora L. (Brazilian cherry), different investigations confirmed the analgesic, anti-inflammatory, anti-hypertensive and anti-diabetic effects of this species. Later studies showed that the same species exhibited antimicrobial and antioxidant activities (Coelho-de-Souza et al., 2004;
Auricchio et al., 2007). The popular use of this species, as well as E. pyriformis Cambess., in the treatment of gout was reported by Schmeda-Hirschmann et al. (1987) and Theoduloz et al. (1988), who showed that flavonoids present in the leaves inhibit xanthine oxidase, an enzyme involved in the conversion of xanthine into uric acid.

Comparatively less studied, E. pyriformis is popularly known as uvaia, uvaieira, uvaia-do-campo, uvalha and uvalha-do-campo. This species occurs in Argentina, Paraguay and in Brazil, where it grows from São Paulo to Rio Grande do Sul (Legrand \& Klein, 1969). This tree has simple leaves that are subcoriaceous and sericeous on the lower surface, a characteristic that gives them a particular brightness. The flowers are solitary and white, and the species flowers from November to January. The fruits are velvety, globose, approximately $2 \mathrm{~cm}$ in diameter, and have an edible pulp. They are mature in January and February, when they turn yellow (Legrand \& Klein, 1969; Lorenzi, 2002), and exhibit elevated levels of phenolic content and antioxidant activity (Rufino et al., 2009).

Given the importance of this taxon, this work 
investigated the morpho-anatomy of the leaf and stem of E. pyriformis, in order to contribute data to what is known about the flora of Brazil, and this medicinal plant and potential vegetal drug.

\section{Material and Methods}

Branches and leaves of Eugenia pyriformis Cambess., Myrtaceae, were collected at the Jardim

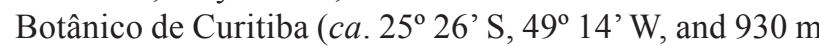
elevation). The species was identified in the Herbário at the Museu Botânico Municipal in Curitiba (PR), where a specimen was archived (voucher number MBM 204990). The collections were made in June 2009, in a sunny fragment of forest surrounded by grassland.

The morpho-anatomical studies were made with mature leaves that were collected from the fourth node on, and with young stems obtained $5-30 \mathrm{~cm}$ from the caulinar apex. The external morphology of the leaves was based on Hickey (1974) and sizes were determined by averaging the measurements taken from at least 20 leaves.

The material was fixed in FAA 70 (Johansen, 1940) and then stored in 70\% (v/v) ethanol (Berlyn \& Miksche, 1976). For the leaves, the petiole and the lower third of the blade were analyzed. Transverse and longitudinal sections, including paradermal, were made by freehand and stained with astra blue and basic fuchsine (Roeser, 1972). Permanent slides were made from part of the fixed material that was dehydrated in an increasing ethanol series and embedded in glycol methacrylate. The embedded material was then sectioned with a rotary microtome and stained with toluidine blue (O'Brien et al., 1964).

For the microchemical tests, freehand sections were made of the fixed material, and the sections were then exposed to the following: hydrochloric phloroglucin to test for lignin (Foster, 1949), Sudan III for lipophilic substances (Sass, 1951), ferric chloride for phenolic compounds (Johansen, 1940), lugol for starch (Berlyn $\&$ Miksche, 1976) and sulfuric acid for calcium crystals (Oliveira \& Akisue, 1997).

The ultrastructural analysis of the surface (using a scanning electron microscope - SEM) (Souza, 1998) was made with leaf material that was fixed, dehydrated in an increasing ethanol series and dried with the $\mathrm{CO}_{2}$ critical point procedure. The material was then mounted on stubs, coated with gold and analyzed in high vacuum.

\section{Results}

The leaves (Figures 1A, 1B) are opposite, simple and approximately $3.5-7 \times 1.5-2.5 \mathrm{~cm}$ with petioles that are $3-6 \mathrm{~mm}$ long. They are symmetric, ellipticlanceolate, with an acute apex and base, entire margin and subcoriaceous texture. The venation is camptodromousbrochidodromous, as the secondary veins do not terminate at the margin, but rather unite to form prominent arcs.

The blade, in surface view, has epidermal cells that are polygonal shaped to slightly wavy on both sides (Figures 1C, 1D), and are covered with a striated cuticle. The stomata are anomocytic and occur on the abaxial surface (hypostomatic leaf) (Figures 1D, 1F). Numerous simple, bent, unicellular non-glandular trichomes, with thick walls and a sharp apex, occur predominantly on the abaxial surface (Figures 1E, 1F).

In transverse section, in the intervein spacing, the epidermis is uniseriate (Figures 2B, 2C), with cells on the adaxial side comparatively larger than those on the abaxial side. The cells of the epidermis are periclinally elongated and covered with a moderately thick cuticle. The stomata are inserted at the same level as the adjacent cells and the guard-cells have evident external cuticular ledges (Figure 2B).

The mesophyll is dorsiventral (heterogeneous, asymmetric) (Figures 2A-2C), generally consisting of one or two layers of palisade parenchyma and approximately seven layers of spongy parenchyma, which represents about $60 \%$ of the height of the chlorenchyma. In the mesophyll there are secretory cavities, mostly near the adaxial surface (Figure 2C), which contain lipophilic substances. There are various crystals of calcium oxalate, mostly of the prismatic type and some druses (Figure 2B). Distributed in the mesophyll, there are small collateral vascular bundles, surrounded by a sclerenchymatic sheath.

In transverse section, the midrib (Figure 2A) has a plano-convex contour. The epidermis is uniseriate, with cells that have convex outer periclinal walls, which are covered by a thick cuticle that forms cuticular flanges. Following this, there are angular collenchyma near both surfaces and one bicollateral vascular bundle in an open arc. This bundle is surrounded by a sclerenchymatic sheath, which is predominantly composed of fibers, and by a crystalliferous sheath. There are also prisms and some druses of calcium oxalate, amyloplasts and phenolic compounds.

The petiole (Figure 2D), in transverse section, is practically circular, but slightly flattened on the adaxial surface. The epidermis is uniseriate and the cuticle is moderately thick with cuticular flanges. The trichomes are similar to those described for the midrib. There are a few layers of angular collenchyma, secretory cavities similar to those in the blade, numerous idioblasts containing prismatic crystals and druses of calcium oxalate and a single bicollateral vascular bundle in an open arc (Figure 2E) that is surrounded by an incipient lignified sheath. Amyloplasts and cells with phenolic compounds are also present. 


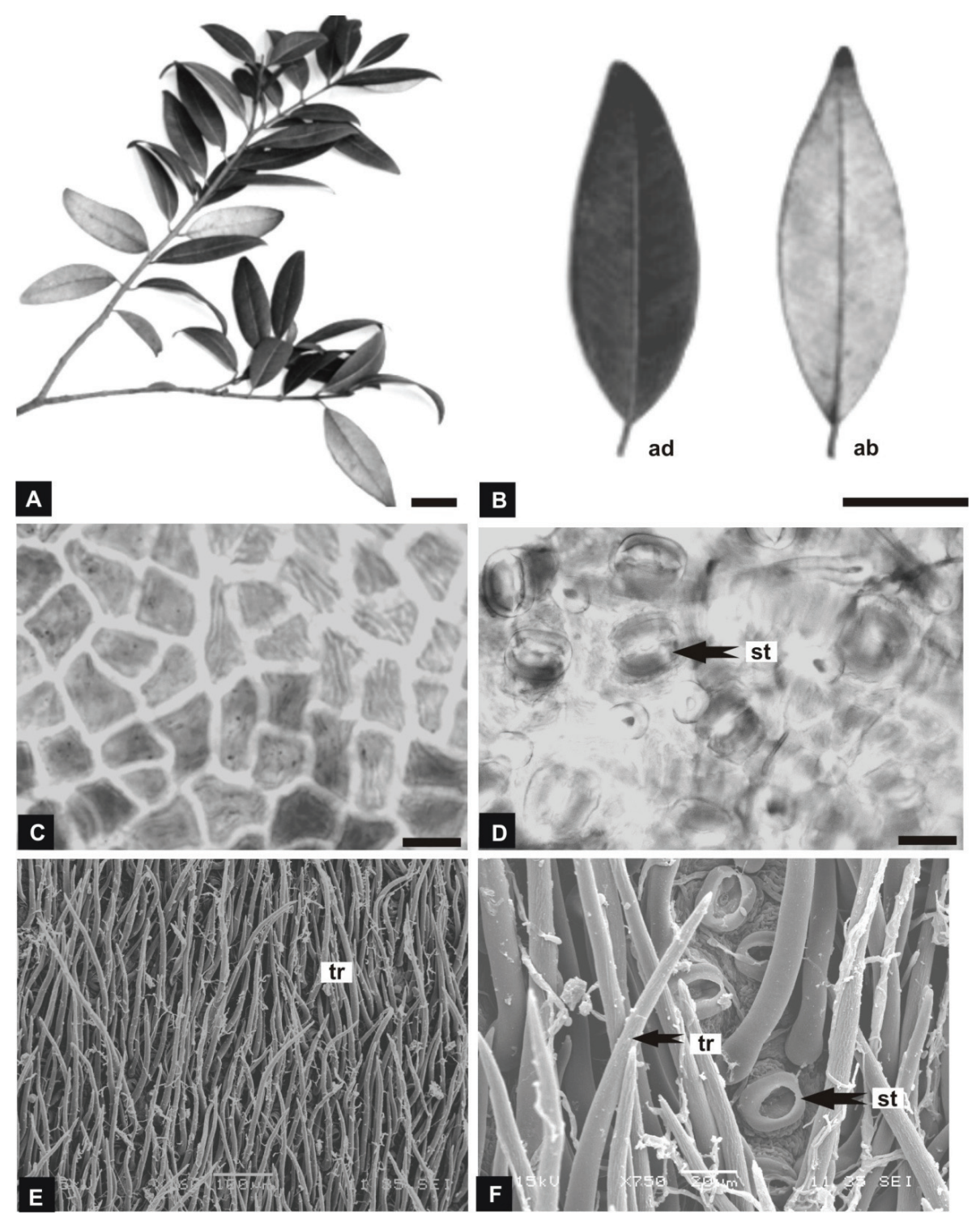

Figures 1. Eugenia pyriformis Cambess., Myrtaceae: A. Vegetative apical branch; B. Simple leaves, adaxial and abaxial surfaces; C. Adaxial surface of the leaf epidermis, in surface view; D. Abaxial side of the leaf epidermis, in surface view; E. Numerous nonglandular trichomes on the abaxial side of the leaf; F. Non-glandular trichomes and stomata on the abaxial surface of the epidermis. Abbreviations: ab: abaxial; ad: adaxial; st: stomatum: tr: non-glandular trichome. Bar $2 \mathrm{~cm}(\mathrm{~A}, \mathrm{~B}) ; 20 \mu \mathrm{m}(\mathrm{C}, \mathrm{D})$

The stem is circular in transverse section, and covered with a periderm (Figures 3A, 3B) that has superficial phellogen. The suber is located on the outer surface, which consists of several layers of tabular cells (Figure 3B) impregnated with suberin and lignin. In the cortex, there are many layers of cortical parenchyma. The vascular cylinder consists of external phloem, xylem and internal phloem, traversed by narrow rays (Figures $3 \mathrm{~A}-3 \mathrm{C})$. The xylem is totally lignified and has tracheary elements of relatively small diameter (Figures 3B, 3C). Fibers and stone cells, which are solitary or in small groups, occur in the cortex, external phloem and pith
(Figures 3B-3D). There are numerous cells with phenolic content, calcium oxalate prismatic crystals (Figure 3D) and some druses.

\section{Discussion}

In relation to the external morphology of the leaf of E. pyriformis, similar aspects were found for the same species by Legrand \& Klein (1969) and Lorenzi (2002). In a study of leaf venation and species identification of Eugenia (Cardoso \& Sajo, 2006), E. pyriformis was reported to have camptodromous-brochidodromous 


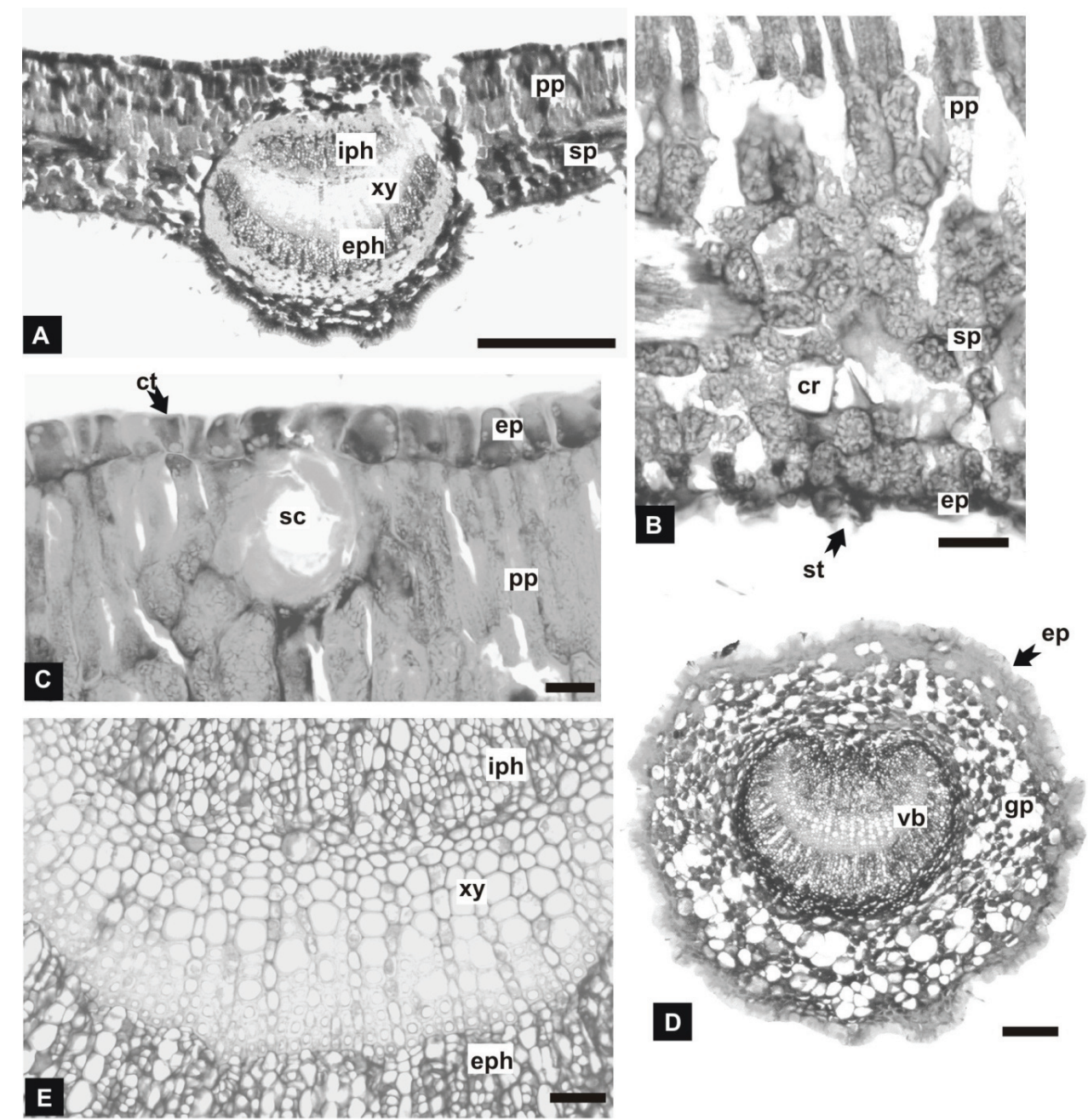

Figures 2. Eugenia pyriformis Cambess., Myrtaceae. Leaf: A. Transverse section of the blade; B. Detail of a stomatum on the abaxial surface and a calcium oxalate prism; C. Detail of a secretory cavity; D. General aspect of the petiole; E. Detail of the vascular bundle of the petiole. Abbreviations: cr: crystal; ct: cuticle: ep: epidermis: eph: external phloem; gp: ground parenchyma; iph: internal phloem; pp: palisade parenchyma; sc: secretory cavity; sp: spongy parenchyma; st: stomatum; vb: vascular bundle; xy: xylem. Bar $20 \mu \mathrm{m}(\mathrm{B}, \mathrm{C}, \mathrm{E}), 10 \mu \mathrm{m}(\mathrm{A}, \mathrm{D})$

venation, which was also found in the present study. In related species, this pattern has been found in $E$. umbelliflora O. Berg (guapê) (Medeiros, 2000) and E. florida DC. (Donato \& Morretes, 2009).

Concerning the leaf anatomy, the features mentioned for the Myrtaceae (Metcalfe \& Chalk, 1950) that were described for E. pyriformis in this analysis were a uniseriate epidermis, non-glandular trichomes, anomocytic stomata, secretory cavities, internal phloem, cells containing phenolic compounds and calcium oxalate crystals. These structures are considered common in the taxon, and occur in other genera of the family, such as Campomanesia adamantium (Cambess.) O. Berg (guabiroba), Myrcia cordifolia O. Berg, M. decrescens O. Berg, M. torta DC. (Gomes et al., 2009), M. sphaerocarpa DC., M. citrifolia (Aubl.) Urb., M. guianensis (Aubl.) DC. (pedra-hume-caá) (Jorge et al., 2000), Hexachlamys edulis (O. Berg) Kausel \& D. Legrand (Lorca et al., 1995) and Melaleuca spp. (Silva, 2007). Although these common aspects are easily distinguished in a microscopic analysis, which could be used as a pharmacognostic control and are taxonomically relevant at the family level, they lack diagnostic value at the species level.

Given this finding, other anatomical characters should be evaluated to help differentiate E. pyriformis. For example, there are amphistomatic leaves and isobilateral mesophyll in species of Melaleuca (Silva, 2007), and long trichomes and a hypodermis in H. edulis (Lorca et al., 1995). These data contradict the present study where E. pyriformis has a hypostomatic leaf, dorsiventral mesophyll, relatively small trichomes and no hypodermis.

In comparison to other members of Eugenia, in general, there are some anatomical similarities among the 


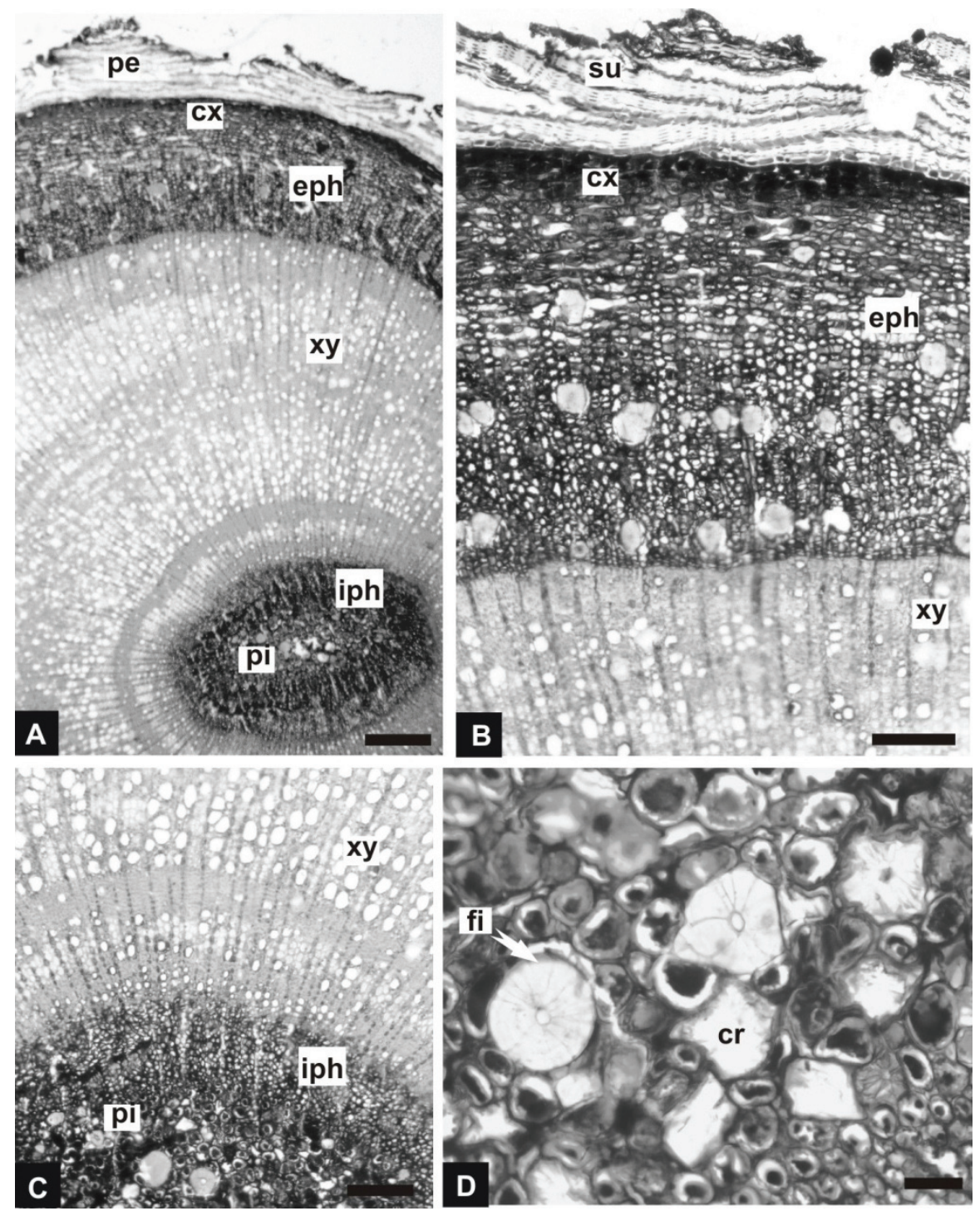

Figures 3. Eugenia pyriformis Cambess., Myrtaceae. Stem, in transverse section: A. General organization; B. Detail of the periderm, cortex, external phloem and xylem; C. Xylem, internal phloem and pith; D. Detail of fibers and prisms in the pith. Abbreviations: cr: crystal; cx: cortex; eph: external phloem; fi: fiber; iph: internal phloem; pe: periderm; pi: pith; su: suber; xy: xylem. Bar $50 \mu \mathrm{m}$ (B, C); $20 \mu \mathrm{m}(\mathrm{A}, \mathrm{D})$

leaves, such as stomata restricted to the abaxial surface, a striated cuticle, polygonal epidermal cells that are wavy in surface view, dorsiventral mesophyll, a midrib with a bicollateral vascular bundle in an open arc that is surrounded by a sclerenchymatic sheath, secretory cavities that mostly occur in the subepidermis, druses and prismatic crystals of calcium oxalate and phenolic compounds (Fontenelle et al., 1994; Lorca et al., 1995; Jorge et al., 2000; Medeiros, 2000; Donato \& Morretes, 2007; 2009; Alves et al., 2008).

The species in this study can be distinguished from similar species because E. uniflora L. has a thin cuticle and paracytic stomata (Lorca et al., 1995). This type of stomata was also reported for E. florida
(Donato \& Morretes, 2009). Isobilateral mesophyll of E. copacabanensis Kiaersk. (Fontenelle et al., 1994) and a concave-convex contour of the midrib, in transverse section, of E. brasiliensis Lam. (grumixama) (Donato \& Morretes, 2007) also represent differentiating elements. These are distinguishing characters assuming that E. pyriformis exhibits a moderately thick cuticle, anomocytic stomata, dorsiventral mesophyll and a planoconvex midrib.

Aspects of the petiole can also contribute towards characterizing species, which was observed by Fontenelle et al. (1994). According to these researchers, E. maricaensis G.M. Barroso has a vascular bundle in a centric arrangement in the petiole, whereas E. schottiana 
O. Berg has a vascular bundle in a closed arc, which differs from the open arc observed in the present work.

However, the diagnostic value assigned to different structures should be considered carefully because these structures might be environmentally influenced (Cutter, 1987). For example, Alves et al. (2008) demonstrated that the dimensions of the leaves of E. uniflora vary between plants that grow in urban and rural environments. The pollutants of cities can be responsible for the smaller leaves, higher proportion of palisade parenchyma, reduction of intercellular spaces, higher density of stomata and higher amount of crystals. In addition, Donato \& Morretes (2007) evaluated E. brasiliensis growing in areas of restinga and forest and concluded that the high incidence of light on the coast determines leaf thickness, thickness and degree of lignification of the cell walls, stomata and vascular density, concentration of ergastic compounds, height of the palisade parenchyma and number of layers of spongy parenchyma. The same authors in a later work (2009) verified that there are differences in the sun and shade leaves of E. florida, and the sun leaves presented the same characteristics as the leaves of the trees growing in restinga in the earlier study.

In the case of secretory cavities, according to Gomes et al. (2009), in species where these cavities are located near the epidermis, the origin is from the epidermal meristem without participation of the ground meristem. Although there were no ontogenetic studies conducted in this work, according to Lorca et al. (1995) these internal secretory structures have a schizolysigenous formation in E. pyriformis.

In reference to the stem, the structural organization in E. pyriformis matches the description by Metcalfe \& Chalk (1950) for the Myrtaceae and Eugenia, consisting of peripheral phellogen, external phloem, xylem and internal phloem forming continuous cylinders traversed by narrow rays, stone cells, phenolic compounds, calcium oxalate crystals and tracheary elements with small lumen.

Although Soffiatti \& Angyalossy-Alfonso (1999) examined thicker mature stems of E. cerasiflora Miq. and E. uniflora, some similarities can be identified when compared to the young stems of E. pyriformis, such as the presence of internal phloem, one to three rows of cells traversing the vascular system, inclusions represented by prismatic crystals, fibers and sclereids. Based on the descriptions given by the cited authors, many of the sclereids are equivalent to the stone cells (brachysclereids) reported in the present study.

Based on the observations made during the present study, morpho-anatomical characters should be considered together to identify E. pyriformis, such as stomata type, stomata location on the leaf epidermis, the type of mesophyll, contour of the midrib and aspects of the vascular bundle in the petiole.

\section{References}

Alves ES, Tresmondi F, Longui EL 2008. Análise estrutural de folhas de Eugenia uniflora L. (Myrtaceae) coletadas em ambientes rural e urbano. Acta Bot Bras 22: 241-248.

Auricchio MT, Bacchi EM 2003. Folhas de Eugenia uniflora L. (pitanga): propriedades farmacobotânicas, químicas e farmacológicas. Rev Inst Adolfo Lutz 62: 55-61.

Auricchio MT, Bugno A, Barros SBM, Bacchi EM 2007. Atividades antimicrobiana e antioxidante e toxicidade de Eugenia uniflora. Latin Am J Pharm 26: 76-81.

Berlyn GP, Miksche JP 1976. Botanical microtechnique and cytochemistry. Ames: Iowa State University.

Cardoso CMV, Sajo MG 2006. Nervação foliar em espécies brasileiras de Myrtaceae Adans. Acta Bot Bras 20: 657-669.

Coelho-de-Souza G, Haas APS, Poser GL, Schapoval EES, Elisabetsky E 2004. Ethnopharmacological studies of antimicrobial remedies in the south of Brazil. $J$ Ethnopharmacol 90: 135-143.

Cutter EG 1987. Anatomia vegetal. São Paulo: Roca.

Donadio LC, Môro FV, Servidone AA 2002. Frutas brasileiras. Jaboticabal: Novos Talentos.

Donato AM, Morretes BL 2007. Anatomia foliar de Eugenia brasiliensis Lam. (Myrtaceae) proveniente de áreas de restinga e de floresta. Rev Bras Farmacogn 17: 426443.

Donato AM, Morretes BL 2009. Anatomia foliar de Eugenia florida DC. (Myrtaceae). Rev Bras Farmacogn 19: 759770.

Fontenelle GB, Costa GC, Machado RD 1994. Foliar anatomy and micromorphology of eleven species of Eugenia L. (Myrtaceae). Bot J Linn Soc 115: 111-133.

Foster AS 1949. Practical plant anatomy. Princeton: D. Van Nostrand.

Gomes SM, Somavilha NSDN, Bezerra KMG, Miranda SCM Carvalho PS, Ribeiro DG 2009. Anatomia foliar de espécies de Myrtaceae: contribuições à taxonomia e filogenia. Acta Bot Bras 23: 223-238.

Hickey LJ 1974. Clasificación de la arquitectura de las hojas de dicotiledóneas. Bol Soc Argent Bot 16: 1-26.

Johansen DA 1940. Plant microtechnique. New York: McGraw-Hill.

Joly AB 1998. Botânica: introdução à taxonomia vegetal. São Paulo: Nacional.

Jorge LIF, Aguiar JPL, Silva MLP 2000 Anatomia foliar de pedra-hume-caá (Myrcia sphaerocarpa, Myrcia guianensis, Eugenia punicifolia- Myrtaceae). Acta Amaz 30: 49-57.

Legrand DC, Klein RM 1969. Mirtáceas. In: Reitz R (org.). Flora ilustrada catarinense. Itajaí: Herbário Barbosa Rodrigues.

Lorca GG, Amat AG, Gonzales C 1995. Análisis comparativo 
de caracteres diagnósticos para la identificación de tres especies argentinas de Myrtaceae empleadas en la medicina popular. Acta Farm Bonaer 14: 81-86.

Lorenzi H 2002. Árvores brasileiras: manual de identificação e cultivo de plantas arbóreas nativas do Brasil. Nova Odessa: Plantarum.

Magina MDA, Pietrovski EF, Gomig F, Falkenberg DB, Cabrini DA, Otuki MF, Pizzollati MG, Brighente IMC 2009. Topical antiinflammatory activity and chemical composition of the epicuticular wax from the leaves of Eugenia beaurepaireana (Myrtaceae). Braz J Pharm Sci 45: 171-176.

Medeiros JD 2000. Anatomia foliar de Eugenia umbelliflora Berg (Myrtaceae). Biotemas 13: 7-20.

Metcalfe CR, Chalk L 1950. Anatomy of the dicotyledons: leaves, stem, and wood in relation to taxonomy with notes on economic uses. Oxford: Clarendon.

O'Brien TP, Feder N, McCully ME 1964. Polychromatic staining of plant cell walls by toluidine blue O. Protoplasma 59: 368-373.

Oliveira F, Akisue MK 1997. Fundamentos de farmacobotânica. São Paulo: Atheneu.

Roeser KR 1972. Die Nadel der schwarzkiefer massenprodukt und kunstwerk der natur. Mikrokosmos 61: 33-36.

Rufino MSM, Alves RE, Brito ES, Perez-Jimenez J, SauraCalixto FD 2009. Total phenolic content and antioxidant activity in acerola, açaí, mangaba and uvaia fruits by DPPPH method. Acta Hort 841: 459-462.

Sass JE 1951. Botanical microtechnique. Ames: Iowa State College.

Schmeda-Hirschmann G, Theoduloz C, Franco L, Ferro EB, Arias AR 1987. Preliminary pharmacological studies on Eugenia uniflora leaves: xanthine oxidase inhibitory activity. J Ethnopharmacol 21: 183-186.

Silva CV, Bilia DAC, Maluf AM, Barbedo CJ 2003. Fracionamento e germinação de sementes de uvaia (Eugenia pyriformis Cambess. - Myrtaceae). Rev Bras Bot 26: 213-221.

Silva CJ 2007. Morfoanatomia foliar e composição química dos óleos essenciais de sete espécies de Melaleuca L. (Myrtaceae). Viçosa, 89 p. Dissertação de Mestrado, Programa de Pós-graduação em Botânica, Universidade Federal de Viçosa.

Soffiatti P, Angyalossy-Alfonso V 1999. Estudo anatômico comparativo do lenho e da casca de duas espécies de Eugenia L. (Myrtaceae). Rev Bras Bot 22: 175-184.

Souza VC, Lorenzi H 2005. Botânica sistemática. Nova Odessa: Instituto Plantarum.

Souza W 1998. Técnicas de microscopia eletrônica aplicadas às Ciências Biológicas. Rio de Janeiro: Sociedade Brasileira de Microscopia.

Theoduloz C, Franco L, Ferro EB, Schmeda-Hirschmann G 1988. Xanthine oxidase inhibitory activity of Paraguayan Myrtaceae. J Ethnopharmacol 24: 179183.

\section{*Corresponcence}

Márcia do Rocio Duarte

Laboratório de Farmacognosia, Departamento de Farmácia, Universidade Federal do Paraná

Av. Pref. Lothário Meissner, 632, 80210-170 Curitiba-PR, Brazil

marciard@ufpr.br

Tel. +55 4133604064 